\title{
Conceptual Nexuses between Sustainable Development and Blue- Green Economy: An Analysis of the Importance of Adopting Blue- Green Economic Principles in Achieving Sustainable Development Goals
}

\author{
Nipuni Dissanayake ${ }^{1}$, Athula Withanawasam ${ }^{1} \&$ Athambawa Sarjoon ${ }^{1 *}$ \\ ${ }^{1}$ Department of Political Science, Faculty of Arts, University of Peradeniya, Peradeniya 20400, Sri Lanka. \\ *Email of Corresponding Author: sarjoona@gmail.com
}

\begin{abstract}
Blue-Green economic principles are considered an important parameter to achieve sustainable development. The United Nations' mandated Sustainable Development Goals (SDGs) also emphasize the importance of adopting Blue-Green economic principles in national development policies to ensure the sustainability of socio-economic development. This paper has paid attention to examine the conceptual nexus between sustainable development and the Blue-Green economy as a condition for achieving Sustainable Development Goals. Using the existing secondary literature available in the forms of literary books, journal articles and reports, this study has found that focusing and adopting conceptual bases of the Blue-Green economy is an unavoidable aspect of achieving many of the important Sustainable Development Goals which are fundamental for achieving other goals.
\end{abstract}

Keywords: Sustainable Development, Blue-Green Economy, Sustainable Development Goals (SDGs).

DOI: $10.7176 / \mathrm{JESD} / 12-6-10$

Publication date:March $31^{\text {st }} 2021$

\section{Introduction}

The concept of 'Sustainable Development' gained global attention with the introduction of the Agenda of Sustainable Development Goals (SDGs) by the United Nations Development Programme (UNDP) in 2015. Sustainable development is a new approach to development that emphasizes achieving economic growth without harming the environment and save the environment for the next generations. On the other hand, the concept of the Blue-Green economy revolves around the sustainable way of getting optimal benefits from the environment and sea while strictly concerning their preservation. Both the SDGs and the Blue-Green Economic are approaches known as people-driven transformative agendas built on the foundation of transparency, accountability, participation and inclusion of the people. In this paper, it has been attempted to disclose the importance of adopting Blue-Green economic principles in achieving Sustainable Development Goals by identifying the conceptual nexuses between sustainable development and Blue-Green economic principles.

\section{Methodology}

This is a conceptual analysis and qualitative study in nature. This study has mainly used secondary data available in different forms. For this, the existing literature in different forms such as scholarly books, journal articles, policy reports, research findings, and official reports of agencies such as the United Nations Development Program (UNDP) and other UN-based and academic research institutions are consulted. The above literature has examined the concepts of Sustainable Development Goals and the Blue-Green Economy extensively. By examining the works of literature, this study has attempted to identify the nexus between the two concepts, their interdependence and the necessity of annexing them together in their implementation.

\section{The Concept of Sustainable Development and Sustainable Development Goals}

We have seen that in many cases, development activities are driven by one particular need, without full concern about the wide range of future impacts of such activities on the environment. Unsustainable development activities can cause not only the degradation of living standards of people but also drastic changes in climate patterns. Today the entire human civilization is depending on petroleum-based fuel energy sources. In near future, human 
civilization will not be able to use fossil power since it is a nonrenewable energy source. It has been predicted that in 2050, petroleum power will no longer be a source of energy. With the rapid rise of sea level due to climate change and global warming, some island states are in front of a huge threat of losing their territories. This grave situation reminds us of the importance of following the sustainable development principles from today individually and collectively. If people continue their unsustainable development approaches continuously, the more frequent and dreadful its repercussions are likely to occur in future. According to the principles of sustainable development, every member of society has a role to play in walking towards a more sustainable world.

\subsection{What is Sustainable Development?}

The concept of sustainable development is simple. It is the idea that the future should be a better, healthier, place than the present. In general, it is a continuous process of satisfying the needs of the present and future generations. Sustainable development is a process that requires us to view our lives as elements of a larger entity. It requires a holistic way of looking at the world and human life. It requires a recognition that other people may not see things like this at all and will have different perceptions, values, philosophies, aims and ambitions. It requires an understanding that the world is multi-faceted, fragmented and complete (Blebitt, 2015:2).

In academic discourse, sustainability has been identified as a capacity to maintain some entity, outcome or process over time. Stoddart et al. (2011) define sustainability as the efficient and equitable distribution of resources intragenerationally and inter-generationally with the operation of socio-economic activities within the confines of a finite ecosystem. Ben-Eli (2015), on the other hand, sees sustainability as a dynamic equilibrium in the process of interaction between the population and the carrying capacity of its environment such that the population develops to express its full potential without producing irreversible adverse effects on the carrying capacity of the environment upon which it depends. According to Thomas (2015), sustainability brings into focus human activities and their ability to satisfy human needs and wants without depleting or exhausting the productive resources at their disposal.

Development, as a concept, has been associated with different meanings, interpretations and theories from various scholars. According to Reyes (2001) development is understood as a social condition within a nation, in which the needs of its population are satisfied by the rational and sustainable use of natural resources and systems. Todaro and Smith (2006) also define development as a multidimensional process that involves major changes in social structures, attitudes, and institutions, as well as economic growth, reduction of inequality, and eradication of absolute poverty.

Sustainable development has become the buzzword in development discourse, having been associated with different definitions, meanings and interpretations (Mensah, 2019). The basic idea of sustainable development is that it is an approach to development that determines to balance the different and competing needs of the environmental, social and economic limitations of the world. United Nations Development Program (UNDP) with the introduction of SDGs in 2015 presents a comprehensive definition of sustainable development. According to the UNDP, "Sustainable development is the development that meets the needs of the present, without compromising the ability of future generations to meet their own needs" (UNDP, 2015). In other words, it reminds the present society about their responsible role in consuming the resources and saving them for the next generations while preserving the environment. As Comporek et al. (2021:228) indicate, sustainable development based on three crucial components: economic growth, social equity for meeting the needs of today's generation, and environmental protection for the ability to meet today's and future generation's needs

One might have the question that 'is sustainable development only about environmental conservation?' The simple answer is 'no.' The scope of sustainable development is broader than the environmental issues. The main objectives of sustainable development are combating climate change, eradicating poverty, reducing economic inequality, innovation and achieving sustainable consumption. It is also about creating a strong, healthy, free and fair society. This includes uplifting personal wellbeing, promote justice, social inclusion and creating an equal society based on free and fair opportunity for all irrespective of the social divisions such as gender, race, ethnicity, religion, political affiliation, etc. The underlying principles of the concept of sustainable development are the assurance of human needs while respecting certain environmental constraints (Klarin, 2018). The next question that arises is that 'if sustainable development focuses on the well-being of the future, then do we need to sacrifice the present on behalf of the future?' The answer tothis question is also 'no.' Sustainable development is about finding more viable ways of getting things done. More feasible methods presented under sustainable development support not only for the future but also for the present. This supposes that we need to change the way we live today.

The Ecological Footprint (EF) and the Carbon Footprint (CF) are two popular concepts that have close links with the concept of sustainable development. The Ecological Footprint is calculated using how much bioproductive 
area (whether land or water), a population would need to produce in sustainably, the renewable resources they consume, and to absorb the waste and by-products they generate, using the present technology. EF and BC are two important factors in the concepts of demand and supply in Economics (Schaefer et al., 2006). A Carbon Footprint is the quantity of greenhouse gases, primarily carbon dioxide, released into the atmosphere by particular human activity. According to the current, average Ecological Footprint of 1.7 global hectares per person, people need the resources of 1.7 capacities of the Earths to fulfil their needs if they continue their usual lifestyles (Evans et al., 2018:1). This highlights the severity of the current unsustainable living patterns. But, adapting to sustainable development methods never means a reduction in the quality of life. Instead of that, sustainable development principles can bring many advantages, both in the short and long terms. For example, if we skip driving for short distances and switching to walking or cycling, it will not only cut off the carbon emission to the air and save our money but also improve our physical health and may prevent some future health hazards.

\subsection{Historical Development of the Concept of Sustainable Development}

The concept of sustainable development has a gradual development throughout history. This concept received its first international attention in 1972 at the United Nations Conference named 'Human Environment' held in Stockholm (Melsah, 2019; Straaten \& Tylecote, 1997). The international community agreed to the notion which is a fundamental principle in sustainable development that both development and environment issues should not be addressed as separate issues, instead they should be managed in a mutually beneficial way. The influence of the publication in 1972 of the Club of Rome's Report: Limits to Growth' also contributed to the development of this concept in its initial phase (Schrijver, 2010).

Then this concept came to the discussion again in 1987 in a report named 'Our Common Future' published by the World Commission on Environment and Development with the suggestions of the Brundtland Commission. This report included the 'classic' definition of sustainable development as 'development which meets the needs of the present without compromising the ability of future generations to meet their own needs', for the first time in history (Schrijver, 2010:9).

Brundtland Commission was appointed to investigate the environmental issues that people had been encountering for a few decades. By that time, it had been identified that unsustainable development activities were posing a negative impact on the world and they should be addressed immediately. This commission has taken into consideration the previous publications including Rachel Carson's 'Silent Spring' (1962), Garret Hardin's 'Tragedy of the Commons (1968), 'The Blueprint for Survival' in the Ecologist magazine (1972) and the Club of Rome's 'Limits to Growth Report' (1972) (Schrijver, 2010).

Following the above conferences and works, the concept of sustainable development received major international recognition at the 'United Nations Conference on Environment and Development - UNCED' held in Rio de Janeiro in 1992 (Jain and Islam, 2015). In there the first international effort was taken to formulate policies for directing the world to the path of sustainable development. The UNCED had several key outcomes for SD articulated in the conference outcome document, namely Agenda 21 (Worster, 1993). It stated that SD should become a priority item on the agenda of the international community and proceeded to recommend that national strategies be designed and developed to address economic, social and environmental aspects of sustainable development (Allen, Metternicht, \& Wiedmann, 2018). More than 100 Heads of States and 178 representatives from national governments attended this summit. World leaders agreed to incorporate sustainable development strategies into future development agendas in their home countries following the proposals of this summit, as a solution to the rapid environmental degradation.

In 2002, again a 'World Summit on Sustainable Development' was held in Johannesburg with the participation of 191 national governments, UN agencies and multilateral financial institutions to assess the progress of the Rio summit recommendations of 1992 (von Schirnding, 2005). The Johannesburg Summit introduced three pillars to sustainable development as a political declaration together with the 'Johannesburg Plan of Implementation' and a range of various partnership initiatives (Schrijver, 2010:10). At this summit, in the path of sustainable development, world leaders agreed on eight measurable Millennium Development Goals (MDGs), to be achieved by 2015, in addition to outlining broad commitments to human rights, good governance and democracy (Blewitt, 2008).

With the relative failure of achieving the MDGs, the Sustainable Development Goals (SDGs) were born at another United Nations Conference on Sustainable Development held in Rio de Janeiro in 2012. Next, the United Nations Conference on Climate Change which is popularly known as the Paris Agreement held in Paris in 2015 was also a significant milestone in the journey of sustainable development. World Leaders who attended this conference gave a collective pledge to take appropriate measures to limit the rise of global warming to a value below $2{ }^{\circ} \mathrm{C}$ from the pre-industry value and pursuing efforts to limit the temperature increase to $1.5^{\circ} \mathrm{C}$ above pre-industrial levels by 
the year 2100 (Gao et al., 2017; Dröge, 2016; United Nations, 2015).

\subsection{Sustainable Development Goals (SDGs)}

In 2015, the United Nations Development Program (UNDP) introduced Sustainable Development Goals (SDGs) into their master development agenda succeeding the Millennium Development Goals (MDGs). SDGs are a set of 17 aspirational 'Global Goals' with 169 targets and 244 indicators between them to be achieved by 2030 (United Nations, 2016). They are as follows:

Goal 1: End poverty in all its forms everywhere

Goal 2: End hunger, achieve food security and improved nutrition and promote sustainable agriculture

Goal 3: Ensure healthy lives and promote well-being for all at all ages

Goal 4: Ensure inclusive and equitable quality education and promote lifelong learning opportunities for all

Goal 5: Achieve gender equality and empower all women and girls

Goal 6: Ensure availability and sustainable management of water and sanitation for all

Goal 7: Ensure access to affordable, reliable, sustainable and modern energy for all

Goal 8: Promote sustained, inclusive and sustainable economic growth, full and productive employment and decent work for all

Goal 9: Build resilient infrastructure, promote inclusive and sustainable industrialization and foster innovation

Goal 10: Reduce inequality within and among countries

Goal 11: Make cities and human settlements inclusive, safe, resilient and sustainable

Goal 12: Ensure sustainable consumption and production patterns

Goal 13: Take urgent action to combat climate change and its impacts

Goal 14: Conserve and sustainably use the oceans, seas and marine resources for sustainable development

Goal 15: Protect, restore and promote sustainable use of terrestrial ecosystems, sustainably manage forests, combat desertification, and halt and reverse land degradation and halt biodiversity loss

Goal 16: Promote peaceful and inclusive societies for sustainable development, provide access to justice for all and build effective, accountable and inclusive institutions at all levels

Goal 17: Strengthen the means of implementation and revitalize the global partnership for sustainable development.

It is worth noting that not only at the governmental level but also the private sector and civil society by themselves strive to achieve the SDGs. Today, the Inter-Governmental Organizations (IGOs) and International NonGovernmental Organizations (INGOs) are performing their unique roles in their functioning states in achieving the SDGs based on the International Cooperation principles. The SDGs and the world's cooperation in the achievement of them matter to all of us because we all have a shared responsibility for our future and that of our planet. These SDGs are still considered as important milestone gained by the UN body concerning the realization of sustainable development including focusing on Blue-Green economy.

\section{The Concept of Blue-Green Economy}

Blue-Green Economy refers to a modern economic development approach based on the principles of ecological conservation and acquiring optimal benefits from the environment and oceans without causing damages. BlueGreen Economy can be divided into two fields as the Blue Economy and the Green Economy.

The classic idea behind the Green Economy is the current economic development has caused severe ecological degradation in a threatening limit and thus the economy should be a component of the ecosystem in which it resides (United Nations Environmental Program, 2012). The United Nations Environment Program (UNEP) and the Green Economy Initiative (GEI) defines a Green Economy as "one that results in improved human well-being and social equity, while significantly reducing environmental risks and ecological scarcities" (Fedrigo-Fazio, D \& Brink, 2012). In its simplest expression, a Green Economy can be thought of as one which is with low carbon emission. The Green Economy concept has gained popularity in international, regional and national policy circles: initially as a response to the financial crisis, but also a motor for growth and development. It is an operational policy agenda to achieve measurable progress at the environment - economy nexus as a 'pillar' of sustainable development implementation to lead the transition to a low carbon, green economies (Georgeson et al., 2017). 
The concept of Green Economy' appeared more than 20 years ago. It has its origins in discussions around environment and development that led to the discussion and promotion of the term 'sustainable development' at the 1992 United Nations Conference on Environment and Development (UNCED) in Rio de Janeiro (known also as the Rio Summit or Earth Summit). The implementation of the Green economy concept was described as a longterm strategy for national economies to overcome the crisis with the objectives of economic recovery; poverty eradication; as well as reducing carbon emissions, and stopping the degradation of ecosystems (Lavrinenko et al., 2019).

But, today the concept of green economy has received significant international attention and has developed and widened its scope into many subfields. It is believed that Green Economy is driven equally by opportunity dominated by the recognition that it can open new opportunities like generating new employment paths and support economic growth. The United Nations Organization mentions this as, "a new engine of growth." (United Nations Development Program, 2012). The United Nations Environmental Program (2011) considers Green Economy as the economy that leads to the improvement of human well-being and social justice and which does not have any ecological downsides. At the operational level, the Green Economy is designed to reduce carbon emissions and pollution; to improve the efficiency of energy and resource usage, and it aims to promote economic growth and development while ensuring the use of natural assets for sustainable development.

It can be identified some major sectors of the Green Economy as follows. The first one is giving priority to renewable energy and the efficient use of electricity. According to the principles of the Green Economy, it has relied much on renewable energy sources like wind and solar, instead of non-renewable resources, like coal and petroleum. The second one is introducing green construction methods to massive cities and urban development projects as well as to small scale construction carried out at the household level. Thirdly, clean transportation has gained a significant place there. Using more non-carbon and low-carbon emission methods of transportation, such as cycling and using more public transport than private vehicles are among simple methods of clean transportation. The fourth aspect is environmental management which discusses how to get the optimal benefits from the environment without causing damages to it (See: Georgeson at al., 2017; Loiseau et al., 2016; Allen, 2012).

Another key feature of the Green Economy is the concern given to the agriculture, forestry and land management practices. It advocates organic crop cultivation and reforesting campaigns. Green economic principles cover the areas of environmentally friendly food manufacturing and processing also. Green tourism which is known as ecotourism is also a part of the Green Economy. It should be mentioned that Green Economy requires the fullest cooperation of the government, public sector and the public regulatory frameworks including research, design and consultation.

Resource efficiency and socially inclusive principles have a great significance in the Green Economy. It includes quality, green jobs that pay a fair wage. High tax or fines on exceeded carbon emission has been also emphasized here. Another concept in the Green Economy is to assign proper values to the services provided by the natural environment and ecosystems. Meanwhile, establishing effective and efficient recycling and reusing systems in societies based on minimum waste has also gained importance there. After consulting the examining of the Green Economy definitions of the UNEP, the Organisation for Economic Co-operation and Development (OECD) and the World Bank; Borel-Saladin and Turok (2013) conclude that a few caveats notwithstanding, the Green Economy provides the tools required to transform economic activity for healthier environments and more inclusive economies.

It can be identified that the 'Green Technologies' often goes parallel with the Green Economy as a subfield of it (See: Guo et al., 2020). This branch has connected with environmentally friendly (clean), safe and healthy technical inventions that promote sustainable growth of resources. Production and transmission of renewable energy, water purification, sewage treatment, solid waste management, air pollution reduction, etc. are some of the areas which show fast growth in Green Technology.

The concept of Blue Economy (BE) is recognized as central for sustainable development that incorporates socioeconomic benefits and ecological conservation. The concept is increasingly being proposed by scholars and policy makers as a useful concept for conserving the world's ocean and the inherent resources (Okafor-Yarwood et al., 2020). The Blue Economy has been defined in many ways by different institutions and scholars. According to the World Bank, Blue Economy is "comprising the range of economic sectors and related policies that together determine whether the use of oceanic resources is sustainable." (The World Bank, 2017:vi). The United Nations Conference on Trade and Development (UNCTAD) defines BE as the economic and trade activities that focus on the ocean-based marine environment, associated biodiversity, ecosystems, species, and genetic resources whilst ensuring conservation ( $\underline{\mathrm{UNCTAD}, 2014})$. The 'Blue Economy' concept seeks to promote economic growth, social 
inclusion, and the preservation or improvement of livelihoods while at the same time ensuring environmental sustainability of the oceans and coastal areas. At its core, it refers to the decoupling of socioeconomic development through ocean-related sectors and activities from environmental and ecosystems degradation (The World Bank, 2017). There are some main characteristics of the Blue Economy. Some of them are inclusiveness marked by stakeholder participation, well-informed, precautionary and adaptive, transparent and accountable, cross-sectorial, comprising a long-term view, innovative, etc. The number of such features can be varied in different contexts (See: Wenhai et al., 2019).

There are some suggested steps in establishing a Blue Economy in a particular state. In the creation of a Blue economy, it should be able to participate in both the public and private sectors. Foster opportunities for entrepreneurship are also one important provision in the Blue Economy. Next, setting clear, measurable and consistent goals and assessing performances accordingly should be done. Finally, sharing information, best practices and learned lessons should be done regularly to formulate the most suitable model of the Blue Economy for a specific geopolitical context.

The ocean is considered the seventh largest contributor to the world economy due to its annual value of goods and services. Many small island nations depend on marine resources and earn economic capital through the activities related to the sea. There are billions of people who depend on the ocean for food, medicine, livelihoods and other economic development activities. Therefore, oceans are very essential in sustaining life on Earth. The Blue Economy concept was first articulated by the Small Island Developing States (SIDS) at the Rio+20 Summit on Sustainable Development in 2012. Scholars who attended the United Nations Conference on Sustainable Development (UNCSD), Rio+20 Summit warned the danger of over-exploitation of marine resources due to the improper manner of consumption. Those who attended the summit also insisted on incorporating provisions for better adaptation mechanisms for coastal and sea resource based-countries. This led to a better understanding and sharper focus on 'Green Economy in a Blue World' or the Blue Economy itself. In this situation, governments were requested to identify the prospects and barriers related to the Blue Economy and formulate the most suitable action plans in their regional contexts.

It can be recognized as several important subfields in the Blue Economy. One of the most popular areas is Blue Energy. This includes offshore wind power, tidal and wave power, ocean thermal energy conversion, etc. The other Blue economic practices comprise aquaculture, maritime, coastal and cruise tourism, deep-sea and short-sea shipping, etc. Acquiring optimal benefits from marine mineral resources (e.g. seabed mining), marine biotechnology (e.g. resources for the pharmaceutical and cosmetic industries), desalination are also some main economic-related activities in the Blue Economy. Income generation and new employment opportunities in coastal protection and maritime security and surveillance activities are gaining popularity nowadays with the focus on achieving Blue Economy. To achieve economic and social benefits from the above-mentioned industries, proper planning is very important. In this case, relevant authorities including government, public sector, IGOs and INGOs should be able to identify their crucial role and formulate the most appropriate practices for their geographical, socio-political and economic context.

\section{The Conceptual Nexuses between Sustainable Development Goals and Blue-Green Economy}

Sustainable development is an approach in development to harness the issues of the competing needs against an awareness of the environmental, social and economic limitations we are currently encountering. A Blue-Green Economy is also a modern approach in development that aims to acquire optimal benefits from the ocean and forests while preserving them. The reality is that it cannot be selected between the environment and the economy. Therefore, we need both for the continuation of our civilization.

It can be identified very often that the Blue-Green Economy shares the same theoretical basis with sustainable development. Both concepts are revolving around the same subject matters; environment and development. Both concepts have attempted to solve the same issues regarding the dichotomy between ecology and economy. It can be also identified in many places that the Blue-Green Economy and sustainable development have similarities in their scope, sometimes with overlapping concepts and theories. In this way, most of the Blue-Green economic principles depend on the theoretical basis of sustainable development. At this point, it can be asserted that the main cause behind the emergence of the Blue-Green economy is the influence of sustainable development.

Both concepts have highly interconnected in nature and therefore they share some of the same subject values. It can be mentioned that both approaches are coping with the challenge of getting the economy into the right path with the long-term view of protecting the Earth. Green economic principles contain some important drives of sustainable development such as adding a price on carbon emission and natural capital, the given significance to 
renewable energy, efficient use of natural resources, the practices of green construction and clean transportation, eco-tourism, environmental management, greening the agriculture, forestry and land management, etc. These facts confirm the idea that the Green Economy has been developed based on the principles of sustainable development.

The principles related to the Blue Economy also present a great inclination towards sustainable development. Blue Economy supposes that adopting sustainable practices can solve the conflict between the traditional economic, cultural and social values and newly emerging ocean-oriented economic activities and guarantee those values for future generations. Blue Economy has a long-term view that ocean-based economic activities can generate new occupations for the rapidly growing population. One of the main concerns of the Blue Economy is to reduce the negative impact of oceans based economic activities on the marine ecosystem. Blue Economy emphasizes the importance of reducing waste and establishing more environmentally efficient, profitable industries which can contribute directly to sustainable productivity and livelihoods.

Goal 14 and 15 of the SDGs also have directly focused on the conservation of oceans and forests. They are Goal 14: "Conserve and sustainably use the oceans, seas and marine resources for sustainable development" and; Goal 15: "Protect, restore and promote sustainable use of terrestrial ecosystems, sustainably manage forests, combat desertification, and halt and reverse land degradation and halt biodiversity loss." But, in there it should be reminded that the whole set of SDGs is related to environmental protection and it has been included more specifically under 14 and 15 goals. Those goals very clearly indicate that they aim to protect oceans and forests while acquiring benefits from them for economic development in a long term.

Both SDGs and Blue-Green Economy share the same vision of improving human well-being and social inclusiveness while significantly reducing environmental risks and ecological degradation. Both strategies agree with the viewpoint that strengthening the governance mechanism is a vital prerequisite in economic development. In there, both the SDGs and Blue-Green economic approaches have given special attention to the improvement of the elements of Good Governance like participatory, consensus-oriented, accountable, transparent, responsive, effective and efficient, equitable and inclusive and follow the rule of law. Both approaches strictly hold the view that corrects the governance structure and eliminates corruption are essential in the achievement of deliberate economic goals.

There are three main capitals in the world as economic, social and environmental. Historically, human civilizations have been built upon converting environmental capital into economic capital. This can be elaborated as converting natural resources into industries. Today, it has been proved that the economic capital has not been reinvested in environmental or social capital and it is merely a one-direction process. Mostly, economically unstable people have been affected by environmentally insensitive development practices. Hence, find ample solutions for balancing these three capitals has become a major duty of the present generation. This is known as sustaining the economy. This difficult, yet possible process includes building a new social capital to alleviate poverty, provide better education and build social infrastructure and creating a healthy community. In this context, it can be recognized that the Blue-Green economy is mutually cooperating with the SDGs to correct the faults of the imbalanced economic activities of the past.

Sustainable development and Blue-Green Economy have a similar notion that modern technology has a limit of replacements for the essential services provided by forests and marine ecosystems. Still, technology cannot produce oxygen, regulate climate, cycling the nutrients, manage the global water cycle, etc. Therefore, both concepts highly appreciate the common viewpoint that environment and development should be able to mutually cooperate and development should not be a disaster to the eco-system of the Earth.

\section{Conclusion}

The reality is that today the global economy is in huge danger in the backdrop of climate change, many other environmental issues and massive, unpredictable challenges like pandemic situations. Under those circumstances, both the SDGs and the principles of the Blue-Green Economy have introduced vital and meaningful economic reforms which can combat the current crises in the environment as well as the economy. As a result of this, today the sustainable development implications all together with Blue-Green economic provisions have been applied to many development related activities by many states in the world with many positive outcomes. This prevailing situation emphasizes the collaboration and strong conceptual nexus between the SDGs and Blue-Green Economy.

Both the SDGs and the principles of the Blue-Green Economy try to cope with the challenges of climate change, global warming, and massive loss of biodiversity and to fulfil the myriads of demands of the growing world population including introducing sustainable income generation methods. Blue-Green Economy firmly follows 
the fact that if it intends to balance the competing needs of the economy and the environment, more attention should be given to the principles of SDGs since they can boost the Blue-Green economic principles. Hence the SDGs and Blue-Green economic principles have cooperated, sharing a common goal of bringing out new economic strategies to get the prevailing unsustainable economy on the right track.

\section{References}

Allen, C. 2012. A guide book to the green economy: Issue-2: exploring green economy principles. New York: United Nations Division for Sustainable Development. [Online] Available: https://sustainabledevelopment.un.org/content/documents/743GE\%20Guidebook\%202\%20-\%20Principles_fi nal.pdf (20 February 2021).

Allen, C., \& Clouth, S. (2012). Green economy, green growth, and low-carbon development - history, definitions and a guide to recent publications. UNDESA: A guidebook to the Green Economy. [Online] Available: https://sustainabledevelopment.un.org/content/docu ments/GE\%20Guidebook.pdf (20 January, 2021).

Allen, C., Metternicht, G., \& Wiedmann, T. (2018). Prioritising SDG targets: Assessing baselines, gaps and interlinkages. Sustainability Science, 14(2), 421-438

Ben-Eli, M. (2015). Sustainability: Definition and five core principles a new framework the sustainability laboratory New York: The sustainability Laboratory. [Online] Available: http://www.sustainabilitylabs.org/assets/img/SL5CorePrinciples.pdf (20 December 2020)

Blewitt, J. (2015). Understanding sustainable development. $3^{\text {rd }}$ Edi. London: Earthscan.

Borel-Saladin, J.M., \& Turok, I.N. (2013). The green economy: incremental change or transformation? Environmental Policy and Governance, 23:209-20.

Chen, S., De Bruyne, C., \& Bollempalli, M. (2020). Blue economy: community case studies addressing the poverty-environment nexus in ocean and coastal management. Sustainability, 12, 4654.

Comporek, M., Kowalska, M., \& Misztal, A. (2021). The sustainable development of transport enterprises in the context of microeconomic conditions: the cash of Central and Eastern European countries. Entrepreneurship and Sustainability Issues, 8(3):226-247.

Dröge, S. (2016). The Paris Agreement 2015 Turning Point for the International Climate Regime. Berlin: Stiftung Wissenschaft und Politik.

Evans, M., Galli, A., Hanscom, L., Huang, S., Lin, D., Mancini, M. S., Martindill, J., Medouar, F., Murthy, A., Neill, E., Wackernagel, M. (2018). Ecological Footprint Accounting for Countries: Updates and Results of the National Footprint Accounts, 2012-2018. Resources, 7, 58.

Fedrigo-Fazio, D., \& Brink, P.T. (2012). Briefing Green Economy: what do we mean by green economy?. Nairobi: United Nations Environment Program.

Gao, Y., Gao, X., \& Zhang, X. (2017). The $2{ }^{\circ} \mathrm{C}$ Global Temperature Target and the Evolution of the Long-Term Goal of Addressing Climate Change-From the United Nations Framework Convention on Climate Change to the Paris Agreement. Engineering 3, 272-278.

Georgeson, L., Maslin, M., \& Poessinouw, M. (2017). The global green economy: a review of concepts, definitions, measurement methodologies and their interactions. Geo: Geography and Environment, 4 (1), e00036.

Global Environment Facility. (2018). Blue Economy. [Online] Available: https://www.thegef.org/sites/default/files/publications/GEF\%20Assembly_BlueEconomy\%20Factsheet_6.19. 18.pdf (16 October 2020).

Guo, M., Nowakoska-Grunt, J., Gorbanyov, J., \& Egorova, M. (2020). Green Technology and Sustainable Development: Assessment and Green Growth Frameworks. Sustainability, 12, 6571.

Klarin, T. 2018. The Concept of Sustainable Development: From its Beginning to the Contemporary Issues. Zagreb International Review of Economics \& Business, 21(1), 67-94.

Lavrinenko, O., Ignatjeva, S., Ohotina, A., Rybalkin, O \& Lazdans, D. (2019). The role of Green economy in sustainable development (Case study: the EU states). Entrepreneurship and Sustainability Issues, 6(3): 11131126.

Loiseau, E., Saikku, L., Antikainen, R., Droste, N., \& Hansjürgens, B. (2016). Green economy and related concepts: an overview. Journal of Cleaner Production, 139, 361-371. 
Mensah, J. (2019). Sustainable development: Meaning, history, principles, pillars, and implications for human action: Literature review, Cogent Social Sciences, 5:1, 1653531.

Okafor-Yarwood, I., Kadagi, N.I., Miranda, N.A.F., Uku, J., Elegbede, I.O \& Adewumi, I.J. 2020. The Blue Economy-Cultural Livelihood-Ecosystem Conservation Triangle: The African Experience. Frontier in Maritime Science, 7,586.

Reyes, G. E. (2001). Four main theories of development: modernization, dependency, word-system, and globalization. Nómadas. Revista Crítica de Ciencias Sociales y Jurídicas, 4(2), 109-124.

Schaefer, F., Luksch, U., Steinbach, N., Cabeça, J., Hanauer, J. (2006). Ecological Footprint and Biocapacity: the world's ability to regenerate resources and absorb waste in a limited time period. Luxembourg: Office for Official Publications of the European Communities.

Schrijver, N. (2010). Development without destruction: the UN and global resource management. Indiana: Indiana University Press.

Stoddart, H., Schneeberger, K., Dodds, F., Shaw, A., Bottero, M., Cornforth, J., \& White, R. (2011). A pocket guide to sustainable development governance. Stakeholder Forum.

Straaten, J. V. D., \& Tylecote, A. (1997). Environment, technology and economic growth: the challenge to sustainable development. Glos: Edward Elgar Publishing Limited.

The World Bank. (2017). The potential of the blue economy: Increasing long-term benefits of the sustainable use of marine resources for small island developing states and coastal least developed countries. Washington DC: The World Bank.

Thomas, C. F. (2015). Naturalizing Sustainability Discourse: Paradigm, Practices and Pedagogy of Thoreau, Leopold, Carson and Wilson: Ph.D Thesis: Arizona State University.

Todaro, M. P., \& Smith, S. C. (2006). Economic development (8th ed.). Reading: Addison-Wesley.

UNCTAD (2014). The Oceans Economy: Opportunities and Challenges for Small Island Developing States. New York, NY: United Nations Conference on Trade and Development.

United Nations Development Programme, (2012). Green Economy in Action: Articles and Excerpts that Illustrate Green Economy and Sustainable Development Efforts. [Online] Available: https://www.un.org/waterforlifedecade/pdf/green_economy_in_action_eng.pdf (15 October 2020).

United Nations Environmental Program. (2012). Green Economy in a Blue World. Nairobi: United Nations Environmental Program. [Online] Available: https://unctad.org/system/files/non-official-document/ted-ditc05122016-cancun-GreenEconomy-Blue-unep.pdf (18 October 2020).

United Nations Environmental Program. 2011. Towards a Green Economy: Pathways to Sustainable Development and Poverty Eradication. [Online] Available https://sustainabledevelopment.un.org/content/documents/126GER_synthesis_en.pdf (10 February 2021).

United Nations, (2015). General Assembly: Resolution adopted by the General Assembly on 25 September 2015. A/RES/70/1. [Online] Available: https://www.un.org/ga/search/view doc.asp?symbol=A/RES/70/1\&Lang=E (2 February 2021).

United Nations, (2015). Paris Agreement. [Online] Available: https://unfccc.int/sites/default/files/english_paris_agreement.pdf (18 October 2020).

United Nations, World Bank Group, (2017). The Potential of the Blue Economy: Increasing Long-term Benefits of the Sustainable Use of Marine Resources for Small Island Developing States and Coastal Least Developed Countries. [Online] Available: https://sustainabledevelopment.un.org/content/documents/2446blueeconomy.pdf (16 October 2020).

von Schirnding, Y. (2005). The World Summit on Sustainable Development: reaffirming the centrality of health. Global Health, 1, 8.

Wenhai L., Cusack C., Baker M., Tao W., Mingbao C., Paige K., Xiaofan Z., Levin L., Escobar E., Amon D., Yue Y., Reitz A., Neves AAS., O’Rourke E., Mannarini G., Pearlman J., Tinker J.., Horsburgh KJ, Lehodey P., Pouliquen S., Dale T., Peng, Z \& Yufeng, Y. (2019). Successful Blue Economy Examples With an Emphasis on International Perspectives. Frontier in Maritime Science, 6:261.

Worster, D. (1993). The wealth of nature: environmental history and the ecological imagination. New York: Oxford University Press. 